\title{
ANALISIS PIUTANG TAK TERTAGIH BERDASARKAN UMUR PIUTANG PADA PT. AIR MANADO
}

\author{
Yulindasari Kiay Demak ${ }^{1}$, Jantje .J. Tinangon ${ }^{2}$, Lidia Mawikere $^{3}$ \\ ${ }^{1,2,3}$ Jurusan Akuntansi, Fakultas Ekonomi dan Bisnis, Universitas Sam Ratulangi, Jl. Kampus Bahu, Manado, \\ 95115, Indonesia \\ Email : Yulindasari.ykd@gmail.com
}

\begin{abstract}
Receivables Represents a number of bills that will be received by a company generally in the form of cash from another parties, as a result of the sale of goods and services on credit. Receivables are often faced with the risk of uncollectibility and sometimes these invoices cannot be avoided and can result in uncollectible receivables / receivables. This research was carried out on PT. Air Manado. The purpose of this study is to analyze the recording of uncollectible receivables on PT. Air Manado, in order to know how to record uncollectible accounts. This study uses descriptive research methods, and data collection techniques used are interview and documentation techniques. The results of this study indicate that the recording of uncollectible accounts at PT. Air Manado it is good because it is in accordance with the provisions and agreement with the investor has also been in accordance with the theory of age method of accounts receivable.
\end{abstract}

Keywords : uncollectible receivables, age of account receivables

\section{PENDAHULUAN}

Perkembangan dunia usaha dan perdagangan di Indonesia sekarang ini semakin pesat dalam era globalisasi yang menuntut perusahaan harus bekerja lebih keras untuk meningkatkan dan mempertahankan kinerja, mengembangkan inovasi dan melakukan perluasan usaha untuk dapat terus bertahan dan bersaing dalam mencapai tujuan yang diinginkan suatu perusahaan. Tujuan perusahaan dapat ditinjau dari sudut pandang ekonomi yaitu untuk memperoleh keuntungan (profit oriented) dan menjaga kelangsungan hidup perusahaan.

Piutang merupakan sejumlah tagihan yang akan diterima oleh perusahaan dalam bentuk kas dari pihak lain, baik sebagai akibat penyerahan barang dan jasa secara kredit yang memberikan pinjaman maupun sebagaai akibat kelebihan pembayaran kas kepada pihak lain. Sebagian bessar piutang timbul dari penyerahan barang dan jasa secara kredit kepada pelanggan. Pada umumnya pelanggan akan menjadi lebih tertarik untuk membeli sebuah product yang ditawarkan secara kredit oleh perusahaan. Piutang yang dapat muncul dari penjualan atau peenyerahan barang dan jasa secara kredit diklasifikasikan sebagai piutang usaha, yang kemudian tidak menutup kemungkinan akan berganti menjadi piutang wesel (Hery 2015:202).

\section{TINJAUAN PUSTAKA}

Konsep Akuntansi. Pontoh (2013:10) mengemukakan bahwa "akuntansi pada umumnya sering disebut bahasa bisnis dan akuntansi pada dasarnya akan menghasilkan informasi dari sebuah sistem akuntansi yang ada di dalam sebuah entitas atau organisasi".Hans Kartikahadi,dkk. (2016:3) "akuntansi adalah suatu sistem informasi keuangan,yang bertujuan untuk menghasilkan dan melaporkan informasi yang relevan bagi berbagai pihak yang berkepentingan".Definisi di atas, dapat disimpulkan bahwa akuntansi merupakan ilmu yang mempelajari bagaimana proses pengolahan data keuangan sehingga 
menjadi sebuah informasi keuangan yang dapat digunakan oleh penggunanya secara baik dan tepat.

Prinsip-prinsip Akuntansi. Menurut Soemarso (2013:18)"prinsip akuntansi adalah sebuah nilai-nilai yang dijadikan panutan dan dipatuhi oleh pembuat standar akuntansi”. Berikut ini adalah prinsip-prinsip akuntansi :

1. Prinsip Harga Perolehan

2. Prinsip Realisasi Penghasilan

3. Prinsip Mempertemukan Pendapatan dan Biaya

4. Prinsip Objektif

5. Prinsip Pengungkapan Penuh

6. Prinsip Konsistensi

Siklus Akuntansi. Menurut Hery (2015:66) "siklus akuntansi adalah sebuah rangkaian tahapan dalam memproses sebuah data keuangan menjadi sebuah laporan keuangan. Siklus akuntansi menggambarkan mengenai tahapan dalam kegiatan akuntansi" yang meliputi : (1) tahap pencatatan; (2) tahap penggolongan; (3) tahap pengikhtisaran; dan (4) tahap pelaporan.

Akuntansi Keuangan. Menurut Hery (2015:19) "Akuntansi keuangan adalah bagian dari akuntansi yang berkaitan dengan penyiapan laporan keuangan untuk pihak luar, seperti pemegang saham, kreditor, pemasok, serta pemerintah. Prinsip utama yang dipakai akuntansi keuangan dalam persamaan akuntansi (asset = liabilitas + equity"."Akuntansi keuangan berhubungan dengan pencatatan transaksi untuk suatu perusahaan atau organisasi dan penyusunan berbagai laporan berkala dari hasil pencatatan tersebut. Laporan ini yang disusun untuk kepentingan umum dan biasanya digunakan oleh pemilik perusahaan untuk menilai prestasi manajer atau dipakai manager sebagai pertanggungjawaban terhadap para pemegang saham". "Hal penting dari akuntansi keuangan adalah adanya Standar Akuntansi Keuangan (SAK) yang merupakan aturan-aturan yang harus digunakan dalam pengukuran dan penyajian laporan keuangan untuk kepentingan eksternal".

Piutang Usaha. "Piutang usaha atau piutang dagang merupakan piutang atau tagihan yang timbul dari penjualan barang dagangan atau jasa secara kredit. Piutang dagang biasanya diberikan penjual kepada pembeli barang dagang atau jasa dasar kepercayaan, tanpa disertai dengan janji tertulis secara formal. Selain piutang dagang, ada juga piutang yang timbul bukan dari penjualan barang dan jasa, misalnya piutang wesel, piutang kepada pemegang saham, piutang deviden, dan lain-lain". (Sari 2015:11). "Piutang merupakan aktiva lancar atau kekayaan perusahaan yang timbul karena ada penjualan secara kredit. Cara penjualan kredit ini merupakan cara yang biasanya dilakukan dalam dunia bisnis untuk dapat menarik para pelanggan pembeli barang dan jasa dalam perusahaan. Piutang (receivable) adalah klaim uang, barang, atau jasa kepada pelanggan atau pihak-pihak lainnya. Untuk tujuan pelaporan keuangan, piutang diklasifikasikan sebagai lancar (jangka pendek) atau tidak lancar (jangka panjang)". "Piutang adalah seluruh uang yang diklaim terhadap entitas lainnya, mencakup perorangan, perusahaan, dan organisasi lainnya. Piutang meliputi semua klaim dalam bentuk uang terhadap pihak lainnya, termasuk individu, perusahaan atau organisasi lainnya. Piutang biasanya memiliki bagian yang signifikan dari aktiva lancar perusahaan”. Menurut Kieso, dkk (2013:346).

Klasifikasi Piutang. Menurut Hery (2015:203) piutang diklasifikasikan sebagai berikut :

1. Piutang Usaha (Accounts Receivable)

2. Piutang Wesel (Notes Receivable)

3. Piutang Lain-lain (Other Receivable)

Jenis-jenis Piutang. Menurut Kieso, dkk (2013:346) piutang dikelompokkan menjadi dua, yaitu sebagai berikut :

1. Piutang Lancar. Piutang lancar merupakan piutang yang akan ditagih dalam masa satu tahun atau selama satu siklus operasi berjalan, mana yang lebih panjang. 
2. Piutang Tidak Lancar. Piutang tidak lancar merupakan piutang yang akan tertagih lebih dari satu tahun.

Piutang selanjutnya diklasifikasikan dalam neraca, yaitu sebagai berikut : (a) Piutang Dagang; dan (b) Piutang Non Dagang.

Pengakuan Piutang Usaha. Menurut Hery (2015:208) "pengakuan piutang usaha yaitu akun piutang usaha yang pertama kali akan timbul oleh karena penjual barang atau jasa secara kredit, yang kemudian dapat diikuti dengan transaksi retur penjualan, penyesuaian atau pengurangan harga jual dan pada akhirnya penagihan (baik tanpa ataupun disertai dengan pemberian potongan penjual)".

Faktor-faktor yang Mempengaruhi Jumlah Piutang. Menurut Riyanto (2013:85) "faktorJumlah faktor yang mempengaruhi jumlah piutang adalah sebagai berikut" :

1. Penjualan Kredit

2. Syarat Pembayaran Penjualan Kredit

3. Ketentuan dalam Pembatasan Kredit

4. Kebijakkan dalam Pengumpulan Piutang

5. Cara Membayar Pelanggan

Piutang Usaha yang Tidak Dapat Ditagih. Menurut Hery (2015:209) "pada saat piutang dicatat, nantinya akan dilaporkan dalam neraca sebagai aset lancar. Piutang usaha yang dilaporkan dalam neraca ini haruslah benar-benar menunjukkan suatu jumlah yang kemungkinan besar dapat ditagih, setelah menghitung besarnya kredit macet. Beban yang muncul atas tidak tertagihnya piutang usaha atau kredit macet akan dicatatt dalam pembukuan sebagai beban operasional, yaitu dengan menggunakan istilah akun" :

a. Beban Kredit Macet (Bad Debst Expensse)

b. Beban Piutang Ragu-ragu (Doubful Accounts Expense)

c. Beban Piutang Yang Tidak Dapat Ditagih (Uncollectible Accounts Expense)

\section{Metode Penghapusan Piutang Tak Tertagih}

Metode Penghapusan Langsung (Direct Write-Off Method). Menurut Hery (2015:211) "Metode penghapusan langsung diterapkan ketika besarnya kredit macet atau piutang usaha adalah sangat kecil, sehingga berdasarkan prinsip-prinsip materialitas maka metode yang simpel ini diperbolehkan dipakai meskipun untuk tujuan pembukuan". Namun secara keseluruhan, menurut prinsip-prinsip akuntansi yang berlaku umum, metode penghapusan langsung tidaklah diperkenankan untuk tujuan pembukuan (book purposes). Berbeda untuk tujuan perhitungan pajak penghasilan (income tax purposes), dimana metode penghapusan langsung ini justru merupakan metode yang wajib (diharuskan).

Metode Pencadangan (Allowance Method). Menurut Hery (2015:213) "Metode pencadangan digunakan sepanjang periode dimana penjualan kredit terjadi untuk mengestimasi mengenai besarnya piutang usaha yang tidak dapat ditagih dibuat, karena perusahaan belum dapat mengetahui mana dari pelanggannya yang tidak bisa membayar maka perusahaan tidak akan mengkredit (menghapus) piutang usahanya secara langsung".

\section{Estimasi Piutang Tak Tertagih}

Persentase dari Jumlah Penjualan. Menurut Hery (2015:215) "cara ini dinamakan sebagai metode laba rugi (income statement method). Berdasarkan pada data historis, sebuah prosentase tertentu dari total penjualan atau total penjualan kredit ditentukan dan digunakan untuk menghitung besarnya estimasi beban kredit macet. Metode ini focus pada penandingan yang layak atas beban piutang tak tertagih terhadap besarnya pendapatan penjualan terkait". Persentase dari Jumlah Piutang Usaha. Menurut Hery (2015:215) "cara ini menekankan penilaian piutang usaha pada nilai bersihnya yang dapat direalisasi, yang nantinya akan dilaporkan dalam neraca atau dengan kata lain cara ini fokus pada penentuan figure piutang 
usaha yang secara nyata dapat ditagih". "Cara ini dapa dibagi menjadi 2 metode, yaitu berdasarkan pada prosentase dari jumlah saldo akhir piutang usaha dan berdasarkan pada pengelompokkan umur piutang".

Metode Saldo Akhir Piutang. Pada metode ini, prosentase dari jumlah saldo akhir piutang usaha yang di estimasikan tidak dapat ditagih ditentukan. Saldo awal akun cadangan piutang tak tertagih akan disesuaikan jumlahnya agar supaya menghasilkan saldo akhir yang nilainya sama dengan hasil prosentase ini.

Metode Umur Piutang. Metode umur piutang pertama kali, piutang usaha akan dikelompokkan berdasarkan pada masing-masing karakteristik umurnya, yang artinya adanya pengelompokan piutang usaha ke dalam kategori berdasarkan atas tanggal jatuh tempo piutang.

Tabel 1. Karakteristik Umur Piutang

\begin{tabular}{lc}
\hline \multicolumn{1}{c}{ Kisaran Umur Piutang } & Persentase \\
\hline Belum jatuh tempo & $2 \%$ \\
Sudah jatuh tempo 1-30 hari & $5 \%$ \\
Sudah jatuh tempo 31-60 hari & $10 \%$ \\
Sudah jatuh tempo 61-90 hari & $20 \%$ \\
Sudah jatuh tempo 91-180 hari & $30 \%$ \\
Sudah jatuh tempo 181-365 hari & $50 \%$ \\
Sudah jatuh tempo diatas 365 hari & $80 \%$ \\
\hline
\end{tabular}

Sumber : Hery (2015:221)

Lamanya umur piutang yang sudah jatuh tempo ini adalah "lamanya hari mulai saat piutang tersebut jatuh tempo hingga laporan umur piutang (aging schedule) dibuat. Berdasarkan umur piutang, piutang yang sudah lama beredar (jatuh tempo) sangat kecil kemunginan untuk bisa ditagih". 


\section{Penelitian Terdahulu}

\begin{tabular}{|c|c|c|c|c|c|c|c|}
\hline No & $\begin{array}{c}\text { Nama } \\
\text { Peneliti/ } \\
\text { Tahun } \\
\end{array}$ & Judul & Tujuan & $\begin{array}{c}\text { Metode } \\
\text { penelitian }\end{array}$ & $\begin{array}{c}\text { Hasil } \\
\text { Penelitian }\end{array}$ & Persamaan & Perbedaan \\
\hline 1. & $\begin{array}{l}\text { Imanuella } \\
\text { Fensi da } \\
\text { Costa / } \\
2015\end{array}$ & $\begin{array}{l}\text { Analisis } \\
\text { Kerugian } \\
\text { Piutang Tak } \\
\text { Tertagih Pada } \\
\text { PT. Metta } \\
\text { Karuna Jaya } \\
\text { Makassar. }\end{array}$ & $\begin{array}{l}\text { Untuk } \\
\text { mengetahui } \\
\text { perlakuan } \\
\text { atas } \\
\text { kerugian } \\
\text { piutang tak } \\
\text { tertagih pada } \\
\text { PT. Metta } \\
\text { Karuna Jaya } \\
\text { Makassar. }\end{array}$ & $\begin{array}{l}\text { Deskriptif } \\
\text { Kuantitatif }\end{array}$ & $\begin{array}{l}\text { Hasil penelitian } \\
\text { menunjukkan } \\
\text { perusahaan } \\
\text { menggunakan } \\
\text { metode } \\
\text { penghapusan } \\
\text { langsung dalam } \\
\text { hal penentuan } \\
\text { beban kerugian } \\
\text { piutangnya.. }\end{array}$ & $\begin{array}{l}\text { Meneliti } \\
\text { piutang tak } \\
\text { tertagih. }\end{array}$ & $\begin{array}{l}\text { Objek } \\
\text { penelitian } \\
\text { dan metode } \\
\text { penelitian. }\end{array}$ \\
\hline 2. & $\begin{array}{l}\text { Christine } \\
\text { Mawitjere } \\
\text { / } \\
2006\end{array}$ & $\begin{array}{l}\text { "Analisis } \\
\text { Piutang Tak } \\
\text { Tertagih } \\
\text { Berdasarkan } \\
\text { Umur } \\
\text { Piutang Pada } \\
\text { Hotel } \\
\text { Berbintang di } \\
\text { Kota } \\
\text { Manado". }\end{array}$ & $\begin{array}{l}\text { Untuk } \\
\text { mengetahui } \\
\text { umur } \\
\text { piutang } \\
\text { lebih lama, } \\
\text { ada lebih } \\
\text { banyak } \\
\text { presentase } \\
\text { piutang tak } \\
\text { tertagih atau } \\
\text { piutang } \\
\text { ragu-ragu } \\
\text { bahwa } \\
\text { keputusan } \\
\text { beberapa } \\
\text { dari semua } \\
\text { hotel di } \\
\text { Manado. }\end{array}$ & $\begin{array}{l}\text { Deskriptif } \\
\text { Statistik }\end{array}$ & $\begin{array}{l}\text { Hasil penelitian } \\
\text { menunjukkan } \\
\text { semakin lama } \\
\text { umur piutang } \\
\text { maka semakin } \\
\text { tinggi } \\
\text { presentase } \\
\text { beban piutang } \\
\text { tak bisa ditagih } \\
\text { yang diambil } \\
\text { oleh beberapa } \\
\text { dari semua } \\
\text { hotel r di } \\
\text { Manado. }\end{array}$ & $\begin{array}{l}\text { Meneliti } \\
\text { piutang tak } \\
\text { tertagih. }\end{array}$ & $\begin{array}{l}\text { Objek } \\
\text { penelitian } \\
\text { dan metode } \\
\text { penelitian. }\end{array}$ \\
\hline
\end{tabular}

\section{METODE PENELITIAN}

Jenis Penelitian. Jenis penelitian yang digunakan dalam penelitian ini adalah deskriptif yaitu berupa study kasus. Study kasus di lakukan pada PT. Air Manado untuk mengetahui dan menganalisis piutang tak tertagih berdasarkan umur piutang.

Tempat dan Waktu Penelitian. Penelitian ini dilaksanakan pada PT. Air Manado yang beralamat pada Jl. Yos Sudarso No. 65 Paal 2 Manado, Sulawesi Utara. Penelitian ini dilakukan selama 2 sampai 3 bulan.

Jenis Data. Kuncoro (2013:145) Data "merupakan sekumpulan informasi yang diperlukan untuk pengambilan keputusan". Jenis data dapat dibedakan menjadi :

a. Data Kuantitatif. Data kuantitatif adalah reduksi data menjadi angka-angka dan menyimpulkan hasil menggunakan statistik,dalam penelitian ini berupa daftar penyisihan piutang berdasarkan umur piutang.

b. Data Kualitatif. Data kualitatif yaitu data yang menggunakan deskripsi prosedur secara naratif atau kata-kata,dalam penelitian ini berupa data mengenai kondisi perusahaan seperti sejarah perusahaan,profil perusahaan,dan struktur organisasi.

Sumber data. Sujarweni (2014:73) "sumber data merupakan subjek dari mana awal data penelitian itu diperoleh. Adapun data yang diperlukan dalam penelitian ini adalah data primer dan data sekunder", yaitu :

1. Data Primer "adalah data yang didapat secara langsung dari sumber data asli. Data primer dalam peneltian ini berupa data yang dikumpulkan,diolah dan diperoleh langsung dari PT.Air Manado adalah berupa laporan piutang perusahaan”. 
2. Data Sekunder "adalah data yang didapat secara tidak lansung. Data sekunder dalam penelitian ini berupa buku-buku sebagai teori, laporan keuangan publikasi perusahaan,makalah dan sebagainya".

\section{Teknik pengumpulan data}

1. Wawancara. Melakukan tanya jawab dengan pihak yang ditunjuk oleh PT. Air Manado yaitu manager keuangan dan akuntansi, tentang piutang beserta penyisihannya.

2. Dokumentasi. Pengumpulan data dilakukan dengan menyalin atau mengcopy dokumen atau catatan berupa dokumen daftar piutang yang di berikan oleh bagian keuangan.

Metode Analisis. Metode analisis yang digunakan dalam penelitian ini adalah metode deskriptif. Penelitian deskriptif adalah metode pembahasan yang sifatnya menguraikan,menggabarkan suatu keadaan sehingga dapat ditarik kesimpulan mengenai pencatatan piutang tak tertagih berdasarkan umur piutang". Analisis data yang digunakan dalam penelitian ini antara lain menganalisis pencatatan piutang tak tertagih berdasarkan umur piutang.

\section{HASIL PENELITIAN DAN PEMBAHASAN}

4.1. Gambaran Umum Perusahaan

Latar Belakang Berdirinya Perusahaan PT. Air Manado PDAM, kota Manado adalah BUMD milik pemerintah kota Manado yang bertugas mendistribusikan air bersih untuk kebutuhan warga kota. Namun seiring berjalan waktu PDAM kota manado tidak mampu lagi memberikan pelayanan air barsih secara optimal. Beberapa masalah mendasar yang menyebakan PDAM tidak mampu lagi beroperasi secara optimal. Sebagian besar kondisi infrakstruktur pengelolaan air dalam keadaan rusak, bak sedimentasi, pulsator, filter, pompapompa, gengset, pipa distribusi, hingga sampai di tingkat pelanggan seperti kerusakan meter air.

1. Tahun 1922 : Sistem penyedian air minum kota manado (jaman Belanda) dengan nama Dinas Air Minum.

2. Tahun 1976 : Perusahan Air Minum (PAM) dibentuk melalui perda No.1/perda/WKMD/1976 tgl. 9 februari 1976.

3. Tahun 1977 : Perusahaan Air Minum (PAM) Disahkan Gubernur kepala daerah Sulawesi utara dengan surat keptusan No. 6 tahun 1977 tanggal 12 Januari 1977.

4. Tahun 1986 : Perusahaan Air Minum (PAM) Menjadi perusahaan daerah air minum kota Madya daerah tingkat II Manado. Tanggal 15 April 1986 kapmen PU. No16/KPTS/1986 tentang penyerahan pengelolahan prasarana dan sarana air bersih dari kota madya daerah tingkat II Manado .Tanggal 17 April 1986 SK walikota madya kepada daerah tingkat II Manado No.288 tahun1986 ditetapkan pelaksanaan daerah Air Minum Manado.

5. Tahun 2000 : Perusahaan daerah kota Madya, daerah tingkat II Manado di rubah menjadi perusahaan Daerah Air Minum kota Manado, berdasarkan SK walikota Manado No. 14 tahun 2000 tanggal 21 oktober dan perda No. 14.

6. Tahun 2000, tanggal 12 Desember 2000, diruba menjadi Peruasahaan Daerah Air Minum kota Manado. Dan diatur lagi dengan surat keputusan walikota manado no. 55 tahun 2011, tanggal 1 maret 2001.

7. Tahun 2005 : "tanggal 22 oktober 2005, pemerinta kota Manado melakukan kerjasama dengan pihak Weterleiding Maats cappiji Drenthe (WMD)".

8. Tahun 2007 : Tanggal 15 februari 2007, PDAM kota Manado menjadi PT. AIR Manado hasil kerjasama Joint Venture Company (JVC) antara tirta Sulawesi B.V (WMD Belanda) dengan PDM kota Manado (Pemkot Manado). 


\subsection{Hasil Penelitian}

Analisis Pencatatan Piutang Tak Tertagih. Piutang timbul akibat adanya transaksi penjualan secara kredit. Piutang usaha yang telah jatuh tempo dan tidak terbayarkan maka akan menimbulkan piutang tak tertagih pada PT.Air Manado.Adapun faktor-faktor yang mempengaruhi keadaan piutang tersebut adalah sebagai berikut :

1. Faktor ekonomi. Dalam proses pemasangan sambungan baru/pemasangan rekening air tidak melakukan penilaian terhadap keadaan ekonomi pelanggan melainkan hanya melakukan penilaian terhadap lokasi pemasangan sambungan air. Hal ini berdampak pada banyaknya penunggakan piutang Karena faktor ekonomi pelanggan yang taraf kehidupannya menengah kebawah.

2. Tingkat kebocoran/kehilangan air. Dalam perusahaan,tingkat kebocoran/kehilangan air sangat berpengaruh terhadap pendapatan penagihan,karena semakin banyak tingkat kebocoran air maka semakin sedikit piutang yang akan ditagih kepada pelanggan.

3. Kapasitas produksi air yang tidak maksimal. Kapasitas produksi air yang tidak maksimal juga merupakan salah satu penentu banyaknya piutang ysng harus ditagih kepada pelanggan karena apabila produksi air tidak maksimal akan mengakibatkan pelanggan tidak merasa puas,sehingga menunggak dalam pembayaran.

4. Kebiasaan pelanggan dalam membayar. Kebiasaan pelanggan membayar kewajibannya melewati tanggal pembayaran / melakukan penumpukan pembayaran,dapat menyebabkan piutang tak tertagih menjadi besar.

Tunggakan dan penumpukan pembayaran yang menjadi piutang perusahaan ini akan di catat berdasarkan lamanya tunggakan. Dan di buat dalam laporan analisis tunggakan termasuk denda. Karena banyaknya pelanggan,penulis mengambil beberapa sampel tunggakan termasuk denda. Total piutang usaha 1-4 bulan sebesar Rp.11.005.857.597,00 dengan total penyisihan sebesar 30\% yaitu Rp.3.301.757.279,10. Total piutang usaha 5-8 bulan sebesar Rp.5.492.520.195,00 dengan total penyisihan sebesar 60\% yaitu Rp.3.395.512.117,00. Total piutang usaha 9-12 bulan sebesar Rp.4.120.547.315,00 dengan total penyisihan sebesar 80\% yaitu Rp.3.296.437.852.00 dan total piutang usaha lebih dari 1 tahun sebesar Rp.45.855.959,607,00 dengan penyisihan sebesar 100\% yaitu Rp.45.855.959.607,00. Total keseluruhan piutang usaha adalah Rp. 66.474.884.714,00 dengan total penyisihan sebesar Rp.55.749.666.855,10.

\begin{tabular}{ccc}
\hline UMUR & JUMLAH & $\begin{array}{c}\text { PERSENTASE PIUTANG } \\
\text { TAK TERTAGIH }\end{array}$ \\
\hline BULAN) & Rp. 11.055 .857 .597 & $4 \%$ \\
$5-8$ & Rp. 5.492 .520 .195 & $8 \%$ \\
$9-12$ & Rp. 4.120 .547 .315 & $10 \%$ \\
$>1$ TAHUN & Rp. 45.855 .959 .607 & $15 \%$ \\
\hline
\end{tabular}

(Sumber : PT.Air Manado)

Piutang usaha pada PT.Air Manado yang berumur $>1$ tahun dikategorikan sebagai piutang tak tertagih. Hal ini sesuai dengan ketentuan Surat Keputusan Direksi yang di dalamnya termasuk kesepakatan dengan pihak investor dalam hal ini Joint Venture Company (JVC). Dari data yang di dapat, diketahui bahwa PT.Air Manado mengalami piutang tak tertagih sebesar $15 \%$ dari jumlah piutang yang berasal dari tunggakan rekening air dan pelanggan non aktif.

\subsection{Pembahasan}

Piutang usaha yang diperkirakan tidak tertagih dicatat berdasarkan umur piutang dengan cara: 
1. Merekap masing- masing piutang yang sudah di tentukan mana yang belum dan sudah jatuh tempo berdasarkan cabang-cabang.

2. Mengklasifikasikan piutang berdasarkan kategori golongan.

3. Piutang yang telah jatuh tempo akan diklasifikasikan menurut berapa lama utang tersebut telah jatuh tempo.

4. Saldo-saldo piutang yang sudah jatuh tempo dijumlahkan lalu dibuatkan penyisihan.

Hal ini sudah sesuai dengan teori metode umur piutang. Piutang usaha yang berumur 1-4 bulan dikategorikan sebagai piutang yang lancar. Sedangkan piutang usaha yang berumur lebih dari 5 bulan termasuk kedalam kategori piutang usaha yang bermasalah yang terbagi dalam kelompok :

a. Piutang kurang lancar, yaitu piutang yang berumur 5 bulan sampai dengan 8 bulan.

b. Piutang tidak lancar,yaitu piutang yang berumur 9 bulan sampai dengan 12 bulan.

c. Piutang macet / tidak tertagih, yaitu piutang yang berumur lebih dari 12 bulan / 1 tahun.

Piutang usaha yang berumur 1-4 bulan akan di buatkan penyisihan piutang sebesar 30\%, 5-8 bulan $60 \%, 9-12$ bulan $80 \%$, dan $>1$ tahun sebesar $100 \%$. Piutang yang berumur lebih dari 1 tahun di sisihkan sebesar 100\% karena dianggap sudah tidak bisa tertagih. Persentase piutang yang sudah tidak dapat ditagih pada PT.Air Manado :

a. 1-4 bulan yang dikategorikan sebagai piutang lancar,memiliki persentase piutang tak tertagih sebesar 4\% dari jumlah Rp. 11.055.857.597 yaitu Rp.442.234.303,88 sebagai kategori piutang lancar jumlah piutang yang tak tertagih masih dalam batas wajar.

b. 5-8 bulan yang dikategorikan sebagai piutang kurang lancar,memiliki persentase piutang tak tertagih sebesar 8\% dari jumlah Rp. 5.492.520.195 yaitu Rp.439.401.615,6 jumlah piutang yang tak tertagih masih dalam batas wajar.

c. 9-12 bulan yang dikategorikan sebagai piutang tidak lancar,memiliki persentase piutang tak tertagih sebesar 10\% dari jumlah Rp. 4.120.547.607 yaitu Rp.412.054.760,7 jumlah piutang yang tak tertagih masih dalam batas wajar.

d. >1 tahun yang dikategorikan sebagai piutang macet/tidak bisa tertagih, memiliki persentase piutang tak tertagih sebesar 15\% dari jumlah Rp. 45.855.959.607 yaitu Rp.6.878.393,491 jumlah piutang yang tak tertagih cukup besar.

Perusahaan memilih menggunakan metode penyisihan/pencadangan piutang (allowance method) karena dirasa lebih efektif dibandingkan harus memakai metode penghapusan langsung (direct write-off method).

\section{KESIMPULAN DAN SARAN}

\subsection{Kesimpulan}

Berdasarkan penelitian yang telah dilakukan pada PT.Air Manado maka dapat disimpulkan bahwa dalam proses pencatatan piutang tak tertagih berdasarkan umur piutang, PT.Air Manado sudah baik dikarenakan pelaksanaanya sudah sesuai dengan ketentuan dan kesepakatan dengan investor yang ada dan sesuai dengan teori metode umur piutang.

\subsection{Saran}

Dalam kesempatan ini penulis akan memberikan beberapa saran yang dapat dijadikan masukan sebagai berikut :

1. Untuk menghindari tunggakan yang dilakukan pelanggan sebaiknya pihak PT.Air Manado perlu membeirikan kebijakan seperti potongan untuk pelanggan yang membayar rekening airnnya lebih dulu dari waktu kredit yang ditetapkan.

2. Denda ditambahkan agar masyarakat jera dan tak terlambat lagi dalam membayar rekening

3. Memperbaiki pelayanan yang ada, diusahakan tidak ada keluhan tentang air macet agar pelanggan lebih terpenuhi kebutuhannya dan tidak menunggak dalam pembayaran. 


\section{DAFTAR PUSTAKA}

Arsyina, A. L. Sari. 2015. Analisis Faktor-faktor Penyebab Piutang Tak Tertagih Pada PT. Pelindo III (Persero) Cabang Tanjung Emas Semarang.

Cahyarini, Manik. 2015. Analisis Umur Piutang Untuk Meminimalisir Piutang Tak Tertagih Pada PT. Bisma Karang Pilang Surabaya

Da Costa, Imanuella Fensi. 2015. Analisis Kerugian Piutang Tak Tertagih Pada PT. Metta Karuna Jaya Makassar. Jurnal Riset Ekonomi, Manajemen, Bisnis dan Akuntansi. Fakultas Ekonomi Universitas Sam Ratulangi Manado. Vol 3 No. 01 (2015).

Hery. 2015. Pengantar Akuntansi Comprehensive Edition. PT. Grasindo. Jakarta.

Horngren, T. Charles. 2012. Akuntansi Biaya Dengan Penekanan Manajerial. Erlangga. Jakarta.

Kartikahadi, Hans. 2016. Akuntansi Keuangan Berdasarkan SAK Berbasis IFRS Buku 1. Jakarta. Salemba Empat.

Kieso, Donald E, Jerry J, Weygandtv \& Terry D, Warfield. 2013. Akuntansi Intermediate. Erlangga, Jakarta.

Kuncoro, Mudjarad. 2013. Metode Riset Untuk Bisnis dan Ekonomi. Salemba Empat. Jakarta. Mawitjere, Christine. 2006. Analisis Piutang Tak Tertagih Berdasarkan Umur Piutang Pada Hotel Berbintang di Kota Manado. Jurnal Riset Akuntansi Going Concern Fakultas Ekonomi Universitas Sam Ratulangi Manado. Vol 1 No. 02 (2006).

Pontoh, Winston. 2013. Akuntansi Konsep dan Aplikasi. Halaman Moeka, Jakarta.

Riyanto, Bambang. 2013. Dasar-dasar Pembelanjaan Perusahaan. Gadjah Mada. Yogyakarta.

Soemarso, S.R. 2013. Akuntansi Suatu Pengantar, Jakarta: Salemba Empat.

Sujarweni, Wiratna V, 2014. Metodologi Penelitian. Penerbit Pustaka Baru Press. Yogyakarta. 